\title{
Pensionable age vs cross-country diversity of economic activity of the near-elderly
}

\author{
Filip Chybalski \\ Department of Management, Lodz University of Technology, Lodz, Poland
}

\begin{abstract}
Purpose - The purpose of this paper is to examine whether cross-country differences in pensionable age explain such differences in economic activity of people at near-retirement age.

Design/methodology/approach - The empirical study uses regression models for macro-panel encompassing 21 European countries in the period 2008-2014.

Findings - Empirical results indicate that pensionable age is a determinant of cross-country differences in employment rate in the near-retirement age group, and less a factor differentiating average effective retirement age. It turns out that other factors matter, including salaries and wages as percentage of GDP (treated as a proxy for the occupational composition of populations across the countries studied), selfemployment, participation in education and training, or self-perceived health.

Social implications - The problem of economic activity at the near-retirement age is complex and cannot be limited to legal regulations concerning pensionable age. The policy aiming at stimulating the economic activity of the near-elderly should include actions on many sides including labour market, pension system, education, training, or health care.

Originality/value - The results complement studies based on the single-country approach and demonstrate that pensionable age does not account for cross-country differences in terms of average effective age of retirement when controlling for other factors. Moreover, factors differentiating effective retirement age and employments rates across countries studied are not similar.
\end{abstract}

Keywords Retirement, Pensions, Labour market, Comparative study, Population aging, Age management

Paper type Research paper

\section{Introduction}

The perception of a pension system as a tool for dividing current gross domestic product (GDP) between the working generation and the generation of pensioners (Barr and Diamond, 2006; Góra, 2008) motivates the search for an actual frontier between them. However, to define this frontier in explicit terms seems impossible. Obviously, it is located close to the pensionable (statutory retirement) age as the role of this age is determined through an appropriate political process or decision is as

(c) Filip Chybalski. Published in Journal of Economics, Finance and Administrative Science. Published by Emerald Publishing Limited. This article is published under the Creative Commons Attribution (CC BY 4.0) licence. Anyone may reproduce, distribute, translate and create derivative works of this article (for both commercial and non-commercial purposes), subject to full attribution to the original publication and authors. The full terms of this licence maybe seen at http://creativecommons.org/licences/by/4.0/legalcode

This work was supported by the National Science Centre (Poland) under Grant Number 2016/23/ B/HS4/01772. 
JEFAS 26,51

such. Therefore, the question about what determines the age at which people retire is fully justified and is very often undertaken by scholars. However, a micro perspective is dominant in investigations in which determinants of retirement are studied. The majority of research includes empirical studies in which micro-data for a given country are employed to test different drivers of economic activity of people at near-retirement age or their motivations behind retirement. A cross-country macro perspective in investigations of this topic is very rare, although it can allow for the inclusion of various differences across countries and identifying more universal determinants of phenomena under investigation, not only specific for a given country. Moreover, such an approach can be more resistant to some political conditioning accompanying pension reforms (including parametric reforms concerning pensionable age). The goal of this paper is to examine whether cross-country differences in pensionable age explain such differences in economic activity of people at near-retirement age. The economic activity is perceived in this paper two-dimensionally, i.e. through the prism of the average effective age of retirement and employment rates in the near-retirement age group (55-64 years).

The paper contributes to the existing literature in the following way. First, it complements results obtained in investigations, dominant in the literature, based on single-country micro-data, as this study is based on a cross-country macro panel. Moreover, micro and macro approach, as well as their integration, is very demanded in economic studies, as indicated by Fornero et al. (2010) concerning analyses of voluntary pension savings. This challenge refers to studies on retirement as well. Second, the economic activity of people at near-retirement age is reflected in two dimensions - average effective age of retirement and employment rates, whereas most studies in this field use one-dimensional approach, limited to retirement age or probability of retirement. Third, the results of the study indicate some determinants of economic activity at near-retirement age, which have been rarely addressed in the literature so far, especially in a cross-country comparative context. This refers mainly to share of salaries and wages in GDP, which can be treated as a proxy for cross-country differences in terms of occupational composition of an economy.

The paper is organized as follows. First, a literature review on determinants of economic activity at near-retirement age is presented. The next section includes an empirical study based on cross-country panel regression models. The paper ends with discussion of the results obtained and final conclusions, including some policy recommendations.

\section{Determinants of economic activity at near-retirement age: a literature review}

In the literature, many studies concerning the issue of retirement timing and the motivations behind it can be found. The picture that arises from them is that retirement is a very complex and multidimensional problem and the age at which people retire is determined by many factors. Certainly, pensionable age is perceived as a natural and obvious driver of retirement. Staubli and Zweimüller (2013) demonstrate that in the case of pension reform in Austria (2000-2003), an increase in the minimum retirement age from 60 to 62 years for men and from 55 to 58.25 years for women results in a decrease in the probability of retirement by almost $19 \mathrm{pp}$. for men aged 60-62 years and by $22.3 \mathrm{pp}$. for women aged 55-58.25. However, a declining probability of retirement does not have a one-to-one effect on the probability of continuing working. This means that some proportion of agents delaying retirement remains economically inactive. These conclusions are confirmed by Manoli and Weber (2016) who analyse the impact of an increase in early retirement age on the labour force exit age (which according to OECD terminology is convergent to effective retirement age). They find 
that a one-year increase in early retirement age results in a 0.4-year increase in average labour force exit age and a 0.5-year increase in average pension claiming age. Bernal and Vermeulen (2014) show that the impact of pensionable age on effective retirement age is significant and stronger in the long term as compared to the short term. This seems logical if one assumes that agents make (at least partially) rational retirement decisions. In this case, they need some time to make changes in some pension system parameters (including pensionable age) into account.

The papers referred above are only a few examples of investigations that demonstrate the trade-off between statutory and effective retirement age. However, the literature indicates many other determinants of the decision about when to retire. The first is the generosity of a pension system whose impact on retirement results indirectly from Feldstein's $(1974,1996)$ hypothesis that generous social security (including the pension system) decreases private savings. However, high pension benefits (e.g. as compared to average wages) can additionally encourage earlier retirement. In fact, it results often in retirement as quickly as possible, i.e. at pensionable age or even at minimum retirement age. The next important factor while making retirement decisions is the labour market situation reflected mainly in the unemployment rate. As mentioned above, one of the many dimensions of the trade-off between the labour market and retirement is early retirement policy, which was an inefficient means to reduce youth unemployment between 1970 and 1990. Another dimension is the perception of retirement by older workers as a means to avoid unemployment. A positive impact of unemployment on retirement or a negative trade-off between unemployment and effective retirement age is demonstrated e.g. by Coile and Levine (2011) as well as by Marmora and Ritter (2015) for the USA or by Dahl et al. (2000) for Norway. Additionally, Ebbinghaus (2006) indicates that unemployment social benefits constitute one of the most important factors stimulating early retirement. They, even more, are pull factors that encourage being paid social benefits than push factors discouraging continued employment.

Other characteristics of the labour market that can matter in the context of retirement decisions are the distribution of the population in terms of occupation and the form of employment. In the case of the former, many studies based on micro-data indicate that the type of job or occupational group through different physical, cognitive or mental requirements of different professions can impact the decision about when to retire (Blekesaune and Solem, 2005; Fisher et al., 2014; Hayward et al., 1989; Vermeer et al., 2016). Sauré and Zoabi (2012) confirm such a trade-off in their original investigation based on macro-data for 38 countries. They demonstrate that the occupational composition of an economy explains a significant part of cross-country differences in terms of the effective retirement age. As for the form of employment, some studies show that self-employment supports a longer working life (Hochguertel, 2010; Parker and Rougier, 2007; Schuetze, 2015). The premise behind such a trade-off can be multidimensional in nature. First, self-employment as a more flexible form of employment can delay the retirement of the near-elderly due to greater possibilities of managing time, involvement or effort input into work as compared to normal employment. Second, in the case of the owners of family companies the support of family members, e.g. children, can reduce the workloads of the near-elderly and postpone their retirement even in case of some health problems. Third, in some countries, pension contributions paid by entrepreneurs (including the owners of family companies) are low which is correlated to the pension benefits paid to them. This means that the generosity of a pension system in the case of such agents is low which, according to previous considerations, can encourage remaining economically active longer.

\section{Economic activity of the near-elderly}


JEFAS

26,51

64

Other factors in retirement decisions refer to demographics and health. Some investigations address the issue of the necessity of increasing the retirement age while facing the aging population process to stimulate economic growth. Peng and Mai (2013) use dynamic computable general equilibrium (CGE) modelling for China and demonstrate the positive impact an increase of retirement age has on labour productivity, GDP, capital markets, household consumption and export. The factor behind these positive effects is inclining the labour supply caused by delaying retirement. The growing labour force decreases wage pressure and inflation, which results in growing labour demand. The effects are growing average household incomes (wages increase less as mentioned before, however, more agents work and earn) as well as increasing saving, and therefore, capital markets develop. Vogel et al. (2015) in their empirical study also support the thesis that increasing retirement age is positive for an economy in the era of aging. They demonstrate that the openness of an economy and its degree of globalization has less of an effect on welfare as compared to a closed economy. It results from demographic conditions that are similar across developed countries. Most of them experience a sharp population aging. Thus, an effective solution to this problem is increasing the retirement age combined with efficient human capital management through investment in education. Other researches show a positive trade-off between an increase in retirement age and the economy (for review: Bauer and Eichenberger, 2016; Bielecki et al., 2016; Lacomba and Lagos, 2006).

Health also is indicated as an important driver of retirement. A direct relationship is obvious - poor health at near-retirement age can accelerate exit from the labour force. An indirect dependence includes labour productivity which can decrease under deteriorating health. Poor health condition is indicated as a more important stimulant of retirement than other economic or financial factors (Disney et al., 2006; Dwyer and Mitchell, 1999; Karpansalo et al., 2004; Szinovacz and Davey, 2005). Other researches also show the importance of health for retirement decisions (Hagan et al., 2009; McGarry, 2004).

The view that pension decisions are difficult is consistent and common in the literature. Barr (2006) writes regarding choices about pension products that "A common problem is that people make bad choices". This can refer to the majority of pension decisions, including those about when to retire. The premise behind this is irrational expectations and bounded rationality as an important bias of decisions made in terms of pensions or consumption smoothing over the life cycle (Binswanger, 2012; Bodie and Prast, 2012; Byrne et al., 2010; Fatas et al., 2007; Knoll, 2010; Kogut and Dahan, 2012; McConnell, 2013; Mitchell and Utkus, 2003; Tapia and Yermo, 2007). That is why knowledge and education are indicated as important factors in retirement decisions, as they can determine agents' behaviour. Van Rooij et al. (2011) using data for The Netherlands confirm a significant positive trade-off between financial knowledge and retirement planning, not vice versa. This means that knowledge is a cause for good and effective retirement planning, not the reverse (i.e. retirement planning is not a cause for financial education). Lusardi and Mitchell (2017) also demonstrate a positive relationship between financial knowledge and skills in pension decisions on the example of the USA, whereas Brown and Graf (2013) for Switzerland. Other authors find a similar relationship for Russia (Klapper and Panos, 2011), Australia (Agnew et al., 2013), Canada (Boisclair et al., 2017) or Germany (Bucher-Koenen and Lusardi, 2011).

As agents make some pension decisions autonomously, retirement can be affected by the rate of return on pension wealth (e.g. reflected by interest rate) as well. One can expect that in the case of high returns on capital markets in the period when an agent is at nearretirement age his or her decision about when to retire can be postponed in the case of high returns or accelerated in the case of low or negative returns. It results from the fact that the accumulated pension wealth at near-retirement age has the greatest value and potential 
returns on it in absolute terms are then higher than previously. This thesis is confirmed by some studies. For instance, Coile and Levine (2011) demonstrate that long-term losses on the capital market can decrease the probability of retirement in the case of well-educated people, which means that they want to rebuild their pension wealth reduced due to negative returns. Similar conclusions are drawn by McFall (2011). Gustman et al. (2010) indicate that the impact of returns on capital markets on the decision about when to retire is affected by the structure of pension wealth (the proportion between wealth accumulated in the public pension system and private pension system; the proportion between wealth accumulated in defined benefit schemes and defined contribution schemes). Gustafson (2017) demonstrates that a stronger trade-off between rate of return and retirement timing is observed in the case of defined contribution schemes than in defined benefit ones.

The literature review shows that in empirical studies on economic activity single-country micro-approach dominates. Their results indicate what determinants of economic activity of people at near-retirement age can be expected. Pensionable age is usually proved to be an important factor. However, the question is whether similar drivers determine cross-country differences in terms of economic activity at near-retirement age perceived two-dimensionally - through the prism of average effective age of retirement and employment rates among people aged 55-64. Especially interesting in the context of this paper is the question about the role of pensionable age in studied cross-country differences.

\section{Methods and data}

The empirical study attempts to verify the impact of cross-country differences in pensionable age on such differences in economic activity of agents at near-retirement age. However, this activity is viewed in two dimensions. The first one is effective retirement age and the other one is employment among people at near-retirement age. The analysis aims to examine if these two dimensions are under a similar impact of pensionable age and other control variables resulting from the previous literature review. Therefore, two measures of economic activity are used: $A E R$ - average effective retirement age (to measure effective retirement age), and $E M P$ - employment rate in the age group 55-64. Such an approach is also justified by quite a different variability of these two indicators across studied countries. For average effective age of retirement relative standard deviation equals $0.03-0.04$ for cross-sectional series in the studied years, whereas for employment rate it is $0.17-0.36$ (depending on year and gender). To realize the aim of the empirical study, a macro panel (cross-sectional time series) covering 21 countries in the period 2008-2014 is used (period selected due to availability of comparable and complete data). The following countries are included: Austria, Belgium, Czech Republic, Denmark, Estonia, Finland, France, Germany, Greece, Hungary, Ireland, Italy, The Netherlands, Norway, Poland, Portugal, Slovakia, Slovenia, Spain, Sweden and the UK. The general formula of the panel regression models estimated can be presented as follows:

$$
y_{i t}=\beta \cdot R A_{i t}+\gamma \cdot \text { CONTROLS } S_{i t}+\alpha_{i}+\varepsilon_{i t}
$$

where:

$y_{i t}=$ a dependent variable $(A E R, E M P)$;

$R A_{i t}=$ pensionable (statutory retirement) age in $i$-th country in $t$-th period;

CONTROL $S_{i t}=$ vector of control variables for $i$-th country in $t$-th period;

$\beta, \gamma=$ vectors of parameters;

$\alpha_{i}=$ individual effects for $i$-th country; and

$\varepsilon_{i t}=$ vector of residuals.

\section{Economic activity of the near-elderly}


JEFAS

26,51

The average effective age of retirement as calculated by OECD is the average age of all persons withdrawing from the labour force in a given period [1]. The employment rate from the Eurostat database for the age group 55-64 is the percentage of employed persons aged 55-64 concerning the comparable total population in this age group [2].

The vector of control variables includes factors which according to theory and the empirical studies discussed previously are expected to be significant determinants of the retirement decisions and economic activity of older people. Some of them refer to each gender separately; some are common for both of them. They are characterized in Appendix where the sources of data (OECD/Eurostat) are also included.

Two types of regression models for panel data are estimated: with fixed and with random individual effects, separately for two genders ( $m$-for males, $f$-for females). The fixed effects (FE) estimator is employed if there exist some factors which are difficult to measure. However, these factors are important as they reflect some specific drivers of the phenomenon modelled which in the case of average effective retirement age or employment rate among the near-elderly can refer to legal regulations, path-dependency or some economic, social, cultural or behavioural factors that are hidden in nature and can vary across countries. The fixed effects estimator allows the inclusion of such factors in the model; however, in an implicit instead of an explicit way. In the case of the random effects (RE) estimator, the inclusion of such unmeasurable variables in the model is motivated mainly by increasing estimator efficiency, not including some hidden factors (as in the case of fixed effects). An important advantage of estimators dedicated for panel (cross-sectional time series) regression in comparison to simple cross-sectional regression or time-series models (used in case of single-country approach) is a reduction of the omitted-variable bias through the inclusion of individual effects (some variables can be omitted intentionally or unintentionally due to complexity of socio-economic phenomena).

In the case of such phenomena as the average effective age of retirement or employment rate among people aged 55-64, the FE estimator should be used first, as some qualitative or quantitative implicit determinants can be expected. However, the RE estimator is also applied in the study. The final evaluation of the FE and RE models and the choice between them is made by application of the Wald test, the Breusch-Pagan test and the Hausman test (Baltagi, 2013; Wooldridge, 2010). Both types of models are presented in the article for comparison purposes; however, only FE models are interpreted in line with Hausman test results.

\section{Results}

In the case of all the models (Tables 1 and 2), the Hausman test confirms that the fixed effects estimator is better for the analysed explanatory variables than the random effects estimator. Thus, FE models are interpreted in the subsequent part of the paper. The results of estimation demonstrate that in the case of both models for average effective retirement age $(A E R)$ for men and women, pensionable age $(R A)$ is not a significant predictor by a used set of control variables. This does not mean that there is no correlation between the average effective age of retirement and pensionable age. The Pearson's correlation coefficient between these two variables for the studied set of data (macro-panel for 21 countries in the years 2008-2014) equals 0.390 in the case of men and 0.629 in the case of women and is statistically significant for $p<0.001$. Moreover, it is statistically significant as calculated for cross-sectional data for each year separately for $p<0.02$. However, in the case of men, the correlation becomes weaker over the studied period (decreases from 0.458 in 2008 to 0.336 in 2014). In the case of women, it remains stable on the level 0.600. It turns out that crosscountry differences in terms of average effective age of retirement are determined by other 


\begin{tabular}{|c|c|c|c|c|c|}
\hline \multirow{2}{*}{$\begin{array}{l}\text { Independent } \\
\text { variables }\end{array}$} & \multicolumn{2}{|c|}{$A E R m$} & \multicolumn{2}{|c|}{$E M P m$} & \multirow{2}{*}{$\begin{array}{l}\text { Economic } \\
\text { activity of the }\end{array}$} \\
\hline & $\mathrm{FE}$ & $\mathrm{RE}$ & $\mathrm{FE}$ & $\mathrm{RE}$ & \\
\hline const & $39.145^{* * * *}$ & $49.908 * * * *$ & $-44.789 * * *$ & $-22.556^{*}$ & \\
\hline$R A m$ & 0.012 & 0.020 & $0.735^{* * * *}$ & $0.683 * * *$ & \\
\hline$A R R m$ & 3.503 & -0.739 & $13.326^{* * *}$ & 6.602 & \\
\hline$H L Y m$ & 0.017 & 0.086 & -0.188 & -0.169 & \\
\hline HEALTHm & $0.066^{* * *}$ & 0.006 & -0.002 & -0.007 & 67 \\
\hline EDUm & 0.005 & -0.005 & $-0.27 * *$ & $-0.204^{*}$ & \\
\hline$E \& T m$ & -0.072 & -0.025 & $0.561 * * *$ & $0.54^{* * * *}$ & \\
\hline SELF_EMPm & -0.012 & $0.139 * *$ & $0.878^{* * *}$ & $0.888^{* * * * *}$ & \\
\hline UNEMPm & 0.009 & $0.082 * *$ & $-0.654^{* * *}$ & $-0.612 * * *$ & \\
\hline$O D R$ & 0.094 & $0.087 * *$ & 0.135 & 0.167 & \\
\hline$I R$ & 0.067 & 0.029 & -0.043 & -0.129 & \\
\hline GDP_PC & 0.108 & $0.175^{* *}$ & $0.650 * * *$ & $0.689 * * *$ & \\
\hline GDP_GROWTH & $-0.066^{* * * *}$ & $-0.052^{* *}$ & $-0.153^{* *}$ & $-0.146^{* *}$ & \\
\hline$I N F$ & 0.023 & 0.038 & $-0.301 * * *$ & $-0.272 * *$ & \\
\hline$S \& W$ & $0.187 * *$ & $0.093 *$ & $0.454^{* *}$ & 0.257 & \\
\hline$L P$ & 0.069 & $-0.089 * *$ & 0.230 & -0.032 & \\
\hline \multicolumn{6}{|l|}{ Test statistics } \\
\hline Breusch-Pagan & & $134.73^{* * * *}$ & & $284.848^{* * * *}$ & \\
\hline Wald & $20.417^{* * * *}$ & & $95.787 * * *$ & & \\
\hline Hausman & & $43.475^{* * *}$ & & $36.669 * * *$ & Table 1. \\
\hline \multicolumn{5}{|c|}{ Note: $p$-value: $*<0.1,{ }^{* *}<0.05, * * *<0.01$} & Models for $A E R$ and \\
\hline \multicolumn{5}{|c|}{ Source: Own computations based on OECD and Eurostat data } & $E M P$ ( $m$-males $)$ \\
\hline
\end{tabular}

\begin{tabular}{|c|c|c|c|c|c|}
\hline \multirow{2}{*}{$\begin{array}{l}\text { Independent } \\
\text { variables }\end{array}$} & \multicolumn{2}{|c|}{ AERf } & \multicolumn{2}{|c|}{ EMPf } & \\
\hline & $\mathrm{FE}$ & $\mathrm{RE}$ & $\mathrm{FE}$ & $\mathrm{RE}$ & \\
\hline const & $37.197^{* * * *}$ & $43.361^{* * *}$ & $-92.81^{* * *}$ & $-57.565^{* * *}$ & \\
\hline$R A f$ & -0.031 & -0.004 & $0.368^{* * * *}$ & $0.318^{* *}$ & \\
\hline ARRf & 2.474 & 2.85 & $16.36^{* * *}$ & $17.919 * * *$ & \\
\hline$H L Y f$ & -0.019 & 0.036 & 0.036 & 0.062 & \\
\hline HEALTHf & 0.033 & 0.023 & 0.062 & 0.064 & \\
\hline$E D U f$ & 0.009 & 0.038 & 0.067 & 0.356 **** & \\
\hline$E \& T f$ & -0.052 & -0.04 & -0.043 & 0.056 & \\
\hline SELF EMPf & -0.085 & 0.049 & $0.962^{* * * *}$ & $1.131^{* * * *}$ & \\
\hline UNEMPf & 0.051 & 0.052 & $-0.256^{* *}$ & $-0.407 * * *$ & \\
\hline$O D R$ & $0.211^{* * * *}$ & $0.137 * * *$ & $0.78^{* * * *}$ & $0.700^{* * * *}$ & \\
\hline$I R$ & 0.078 & 0.032 & -0.136 & -0.192 & \\
\hline GDP_PC & $0.144^{* *}$ & $0.177^{* * * *}$ & $0.555^{* * *}$ & $0.396^{* *}$ & \\
\hline GDP_GROWTH & -0.034 & $-0.047 * *$ & $-0.222 * * * *$ & $-0.212 * * * *$ & \\
\hline$I N F$ & $0.068^{*}$ & $0.076^{*}$ & 0.067 & 0.108 & \\
\hline$S \& W$ & $0.288^{* * * *}$ & $0.175^{* * * *}$ & $0.632 * * * *$ & 0.231 & \\
\hline$L P$ & -0.005 & $-0.078 * *$ & $0.571^{* * *}$ & $0.208^{*}$ & \\
\hline \multicolumn{6}{|l|}{ Test statistics } \\
\hline Breusch-Pagan & & $92.297 * * *$ & & $165.909^{* * *}$ & \\
\hline Wald & $24.209 * * *$ & & $97.435^{* * *}$ & & \\
\hline Hausman & & $48.723 * * *$ & & $97.096^{* * * *}$ & Table 2. \\
\hline \multirow{2}{*}{\multicolumn{5}{|c|}{$\begin{array}{l}\text { Note: } p \text {-value: } *<0.1, * *<0.05, * * *<0.01 \\
\text { Source: Own computations based on OECD and Eurostat data }\end{array}$}} & Models for $A E R$ and \\
\hline & & & & & $E M P(f$-females $)$ \\
\hline
\end{tabular}


JEFAS

26,51

68

factors. In the case of men, these are self-perceived health, GDP growth, and salaries and wages as percentage of GDP. In the case of women, these are old-dependency ratio, GDP per capita and salaries and wages as per cent of GDP.

Much more significant determinants are observed in the case of employment rates. First, pensionable age is an important determinant of employment among people at nearretirement age for both genders. This trade-off remains statistically significant despite a significant impact of such control variables as inter alia aggregate replacement ratio (men and women), a participation rate of people aged 50-74 years in education and training (men), self-employment in the age group 55-74 (men and women), unemployment obviously (men and women), GDP per capita (men and women), GDP growth (men and women) or salaries and wages as per cent of GDP (men and women).

In the estimated models, the signs of parameters next to the majority of statistically significant predictors are consistent with expectations resulting from the literature review or intuition. The positive impact of self-perceived health on average effective age of retirement or the negative impact of overall unemployment on employment among the near-elderly is obvious and widely commented on in the literature. However, a positive impact of participation of people aged 50-74 in education and training demonstrates that the level of human capital and competitiveness in the labour market matters in the case of the employment of people at near-retirement age. The results show a positive impact of selfemployment in the age group 55-74, which is consistent with the theoretical justification presented above. Moreover, a positive impact of such variables as GDP per capita, labour productivity, and especially salaries and wages as per cent of GDP (the last one is observed in all the FE models for both genders) suggests that the occupational distribution of the population is a significant determinant of cross-country differences in economic activity of people at near-retirement age. Such variables as GDP per capita or labour productivity are expected to be higher in more developed countries, i.e. in countries in which the share of the population employed in more advanced professions in technological or cognitive terms is higher. The same refers to salaries and wages as a percentage of GDP. Thus, the fact that economic activity in the dimension of the average effective age of retirement or employment rate is higher in countries in which GDP per capita is greater, labour productivity is greater or - which is the most important in this case - the share of salaries and wages in GDP is greater, constitutes an argument supporting the thesis that occupational composition matters regarding cross-country differences in terms of economic activity of people at nearretirement age.

The differences in the models for average effective age of retirement and employment rate in the age group 55-64 prompt an examination of whether there is a trade-off between these two variables. Therefore, the models for the employment rate for the age group 55-64 (EMP) with an average effective age of retirement $(A E R)$ as the main tested predictor (instead of $R A-$ pensionable age) with an unchanged vector of control variables (i.e. a vector like that used in the models for $A E R$ and $E M P$, presented in Tables 1 and 2) are estimated additionally (Table 3). In the case of the model for men, the average effective age of retirement is an insignificant predictor which is a bit surprising, particularly due to a significant impact of pensionable age on the employment rate among men aged 55-64 in the model presented in Table 1 . What significantly explains this employment rate is participation in education and training, self-employment, GDP per capita, inflation and salaries and wages as percentage of GDP. The employment rate is negatively correlated to unemployment. In the case of women, the employment rate is affected not only by the average effective age of retirement but also by self-employment, old-dependency ratio, GDP per capita, GDP growth, salaries and wages as per cent of GDP and labour productivity, remaining negatively correlated to unemployment. 


\begin{tabular}{|c|c|c|c|c|c|}
\hline $\begin{array}{l}\text { Independent } \\
\text { variables }\end{array}$ & $\mathrm{FE}$ & $\mathrm{RE}$ & $\mathrm{FE}$ & $\mathrm{RE}$ & $\begin{array}{l}\text { Economic } \\
\text { activity of the } \\
\text { near-elderly }\end{array}$ \\
\hline const & -15.187 & -13.109 & $-86.067 * * *$ & $-74.599 * * * *$ & \\
\hline$A E R(\mathrm{~m} / \mathrm{f})$ & 0.363 & $0.758^{* * * *}$ & $0.463 * *$ & $0.849 * * *$ & \\
\hline $\operatorname{ARR}(\mathrm{m} / \mathrm{f})$ & 9.21 & 1.599 & $15.932 * * *$ & $16.602^{* * * *}$ & \\
\hline$H L Y(\mathrm{~m} / \mathrm{f})$ & -0.26 & -0.283 & 0.016 & 0.019 & \\
\hline $\operatorname{HEALTH}(\mathrm{m} / \mathrm{f})$ & 0.002 & 0.02 & 0.042 & 0.035 & 69 \\
\hline$E D U(m / f)$ & -0.157 & 0.015 & 0.101 & $0.389 * * *$ & \\
\hline$E \& T(\mathrm{~m} / \mathrm{f})$ & $0.554^{* * * *}$ & $0.592^{* * *}$ & -0.013 & 0.104 & \\
\hline$S E L F \_E M P(m / f)$ & $0.903^{* * * *}$ & $0.743^{* * * *}$ & $1.088^{* * * *}$ & $1.204^{* * * *}$ & \\
\hline$U N E M P(m / f)$ & $-0.499 * * *$ & $-0.517 * * *$ & $-0.2^{* * *}$ & $-0.375^{* * * *}$ & \\
\hline$O D R$ & 0.199 & 0.059 & $0.7 * * *$ & 0.531 **** & \\
\hline$I R$ & -0.143 & $-0.28^{*}$ & -0.205 & $-0.249^{*}$ & \\
\hline$G D P \_P C$ & $0.657 * * *$ & $0.691 * * *$ & $0.529 * * *$ & $0.302 *$ & \\
\hline GDP_GROWTH & -0.103 & -0.093 & $-0.196^{* * *}$ & $-0.169 * * *$ & \\
\hline$I_{N F}^{-}$ & $-0.214^{*}$ & $-0.228 *$ & 0.033 & 0.037 & \\
\hline$S_{-} W$ & $0.433 *$ & 0.152 & $0.486 * *$ & 0.078 & \\
\hline$L \bar{P}$ & 0.053 & -0.158 & $0.513 * * *$ & $0.249 * *$ & \\
\hline \multicolumn{6}{|l|}{ Test statistics } \\
\hline Breusch-Pagan & & $150.511^{* * * *}$ & & $142.937 * * *$ & \\
\hline Wald & $44.285^{* * * *}$ & & $68.267 * * *$ & & Models for $E M P$ with \\
\hline Hausman & & $53.870 * * *$ & & $79.519 * * *$ & $A E R$ as predictor \\
\hline \multicolumn{5}{|c|}{ Note: $p$-value: $*<0.1, * *<0.05, * * *<0.01$} & ( $m$-males and \\
\hline \multicolumn{5}{|c|}{ Source: Own computations based on OECD and Eurostat data } & $f$-females) \\
\hline
\end{tabular}

Additionally, there exists a positive trade-off between the aggregate replacement ratio and employment among females aged 55-64.

\section{Discussion}

Some of the results obtained about cross-country differences in economic activity of people at near-retirement age confirm conclusions drawn in previous research, most often based on single-country micro approach. In the case of effective retirement age for men such a driver is health (which confirms results obtained by Disney et al., 2006; Dwyer and Mitchell, 1999; Hagan et al., 2009; Karpansalo et al., 2004; McGarry, 2004; Szinovacz and Davey, 2005). Some other factors that according to the literature affect the decision about when to retire, in this study affect the employment rate among people at near-retirement age. These are mainly pensionable age (which affects retirement decisions in studies by Bernal and Vermeulen, 2014; Manoli and Weber, 2016; Staubli and Zweimüller, 2013), self-employment (which affects retirement decisions in studies by Hochguertel, 2010; Parker and Rougier, 2007; Schuetze, 2015) or unemployment (affecting decisions about retirement in investigations conducted by Coile and Levine, 2011; Dahl et al., 2000; Ebbinghaus, 2006; Marmora and Ritter, 2015).

However, some determinants of cross-country differences identified in this paper are rarely investigated in the literature. The study conducted demonstrates a positive trade-off between the share of salaries and wages in GDP and both the average effective age of retirement and the employment rate in the near-retirement age group. As salaries and wages in GDP (percentage) can be perceived as a good proxy for the occupational composition of an economy, the results obtained suggest the impact of this composition on cross-country differences in terms of average effective retirement age, as demonstrated by Sauré and Zoabi (2012) for 
JEFAS

26,51 macro-data, as well as in terms of employment rate. They are also consistent with the results of many studies conducted on micro-data in which the relationship between the occupation and retirement timing is investigated (Blekesaune and Solem, 2005; Fisher et al., 2014; Hayward et al., 1989; Vermeer et al., 2016). Additionally, the models estimated indicate a positive impact of GDP per capita on average effective age of retirement (in case of females) or employment rate in the age group 55-64 (in case of both genders). In the case of women, a positive relationship between the employment rate and labour productivity is observed as well. This reinforces the view that occupation matters regarding the economic activity of agents in the 55-64 age group as the distribution of population among different professions can be reflected not only in salaries and wages expressed as percentage of GDP but also by average productivity in the economy or GDP per capita. Moreover, the study demonstrates the positive impact participation in education and training has on the employment rate among men aged 55-64. This indicates that cross-country differences in the actions (on individual, companies or public level) aiming at maintaining competitiveness in the labour market through investment in the human capital of older workers differentiate economic activity at near-retirement age.

The models for average effective retirement age suggest that the explanatory properties of pensionable age as a predictor of cross-country differences are quite weak when controlling for occupational distribution. This is consistent with findings by Sauré and Zoabi (2012) who indicate occupational distribution as the main determinant of cross-country differences in terms of effective retirement age. It results inter alia from the fact that there exist some occupations for which a lower statutory retirement age is applied. Thus, cross-country differences in occupational distribution expressed by salaries and wages as percentage of GDP can represent, at least partially, such differences in terms of pensionable age. Therefore, the study does not undermine the conclusion that pensionable age impacts the age at which people retire in a given country (as usually proven in micro-data studies) but demonstrates that pensionable age does not account for cross-country differences in terms of the average effective age of retirement when controlling for other factors.

The results obtained also suggest a negative impact of GDP growth on the economic activity of people at near-retirement age. It is worth emphasising that the literature usually addresses a reversed relationship, i.e. an impact of retirement age on GDP growth or welfare (Bielecki et al., 2014; Kuhn and Prettner, 2016; Peng and Mai, 2013). However, this trade-off can be bidirectional as the agent can take the overall economic situation (expressed by GDP growth) into account while deciding about when to retire. This study suggests that GDP growth as a proxy for economic conditions may determine expectations for the future. According to them, a greater economic growth is perceived as a good prospect for the future that encourages retirement (leisure instead of working). However, this hypothetical relationship requires further investigation.

\section{Conclusions}

The goal of the paper was to answer the question of whether cross-country differences in pensionable age explain such differences in economic activity of people at near-retirement age. It turned out that although pensionable age matters in case of differences in terms of employment rate, it does not affect cross-country diversity of average effective age of retirement. The fact that differences in average effective age of retirement are not significantly subject to the impact of pensionable age is mainly explained by the fact that the cross-country differences in the occupational distribution of the population matter. There are two main premises behind this. The first one is a differentiated statutory retirement age across occupations. The other one is the differences in terms of physical, 
mental or cognitive demands across professions. This is enforced by the fact that selfperceived health also matters which refers to men, among whom physically demanding occupations are more common. Moreover, the fact that self-perceived health is an important factor in models for the average effective age of retirement only in the case of men and not in the case of women, also finds an explanation. Namely, women remain healthy longer, live longer, however, retire earlier. This justifies that they do not perceive health constraints in the context of retirement so much as males do as females retire probably more often (than men) before experiencing serious health problems. The study also proves how important investment in the human capital of people at near-retirement age is, reflected by participation in education and training as it matters in the context of cross-country differences in terms of employment rates among men aged 55-64. This unambiguously suggests that the policy aiming at stimulating the economic activity of the near-elderly should include actions on many sides - on the side of health care, which results from the previous conclusion but also on the side of the pension system and the side of the labour market. In the case of the pension system, retirement age regulations are especially important. In the case of the labour market, actions undertaken by the government and employers including effective and efficient age-management strategies matter. Although demographics is unchangeable in the short run, quantitative intergenerational relations between working and retiring agents can be stimulated by keeping older people in the labour market longer. Pensionable age is not a sufficient means to achieve this goal.

The study conducted has some obvious limitations, especially referring to methodology not allowing for direct inference in terms of some causal relationships between economic activity of people at near-retirement age and mentioned factors. It is possible in the case of long time-series data, which are rarely available in the case of pension system characteristics. On the other hand, cross-country regression based on panel data has an important advantage over single-country approach or cross-country approach based on cross-sectional data, which is the possibility to control for some unobservable omitted variables through the inclusion of individual effects in the models. The results obtained also indicate the need for a more in-depth analysis of the trade-off between the occupational composition of an economy and the economic activity of people at near-retirement age with the use of variables directly reflecting the professional distribution of population across countries.

\section{Notes}

1. A detailed description of the calculating methodology is available at http://www.oecd.org/els/ emp/39371923.pdf (available at 8 January 2019).

2. https://ec.europa.eu/eurostat/statistics-explained/index.php?title=Glossary:Employment_rate (available at 8 January 2019).

\section{References}

Agnew, J.R., Bateman, H. and Thorp, S. (2013), "Financial literacy and retirement planning in Australia", Numeracy, Vol. 6 No. 2.

Baltagi, B.H. (2013), Econometric Analysis of Panel Data, Wiley, Chichester.

Barr, N. (2006), "Pensions: overview of the issues", Oxford Review of Economic Policy, Vol. 22 No. 1, pp. 1-14.

Barr, N. and Diamond, P. (2006), “The economics of pensions", Oxford Review of Economic Policy, Vol. 22 No. 1, pp. 15-39. 
JEFAS 26,51

Bauer, A.B. and Eichenberger, R. (2016), "Endogenous aging: how statutory retirement age drives human and social capital", available at: https://editorialexpress.com/cgi-bin/conference/ download.cgi?db_name=RESConf2017\&paper_id=481 (accessed 18 October 2017).

Bernal, N. and Vermeulen, F. (2014), "The impact of an increase in the legal retirement age on the effective retirement age", De Economist, Vol. 162 No. 2, pp. 115-145.

Bielecki, M.Goraus, K.Hagemejer, J. and Tyrowicz, J. (2014), "The sooner the better - the welfare effects of the retirement age increase under various pension schemes, No. 12/2014 (129), Warsaw", available at: http://www.wne.uw.edu.pl/inf/wyd/WP/WNE_WP129.pdf (accessed 18 October 2017).

Bielecki, M., Goraus, K., Hagemejer, J. and Tyrowicz, J. (2016), "Decreasing fertility vs increasing longevity: raising the retirement age in the context of ageing processes", Economic Modelling, Vol. 52, pp. 125-143.

Binswanger, J. (2012), "Life cycle saving: insights from the perspective of bounded rationality", European Economic Review, Vol. 56 No. 3, pp. 605-623.

Blekesaune, M. and Solem, P.E. (2005), "Working conditions and early retirement: a prospective study of retirement behavior", Research on Aging, Vol. 27 No. 1, pp. 3-30.

Bodie, Z. and Prast, H. (2012), "Rational pensions for irrational people: behavioral science lessons for The Netherlands", in Bovenberg, L., van Ewijk, C. and Westerhout, E. (Eds), The Future of Multi-Pillar Pensions, Cambridge University Press, Cambridge, pp. 299-329.

Boisclair, D., Lusardi, A. and Michaud, P.C. (2017), "Financial literacy and retirement planning in Canada", Journal of Pension Economics and Finance, Vol. 16 No. 3, pp. 277-296.

Brown, M. and Graf, R. (2013), "Financial literacy and retirement planning in Switzerland", Numeracy, Vol. 6 No. 2, pp. 1-23.

Bucher-Koenen, T. and Lusardi, A. (2011), "Financial literacy and retirement planning in Germany", Journal of Pension Economics and Finance, Vol. 10 No. 4, pp. 565-584.

Byrne, A., Blake, D. and Mannion, G. (2010), "Pension plan decisions", Review of Behavioural Finance, Vol. 2 No. 1, pp. 19-36.

Coile, C.C. and Levine, P.B. (2011), "The market crash and mass layoffs: how the current economic crisis may affect retirement", The B. E. Journal of Economic Analysis and Policy, Vol. 11 No. 1, pp. 1-40.

Dahl, S.-A., Nilsen, O.A. and Vaage, K. (2000), "Work or retirement? Exit routes for Norwegian elderly", Applied Economics, Vol. 32 No. 14, pp. 1865-1876.

Disney, R., Emmerson, C. and Wakefield, M. (2006), "Ill health and retirement in Britain: a panel databased analysis", Journal of Health Economics, Vol. 25 No. 4, pp. 621-649.

Dwyer, D.S. and Mitchell, O.S. (1999), "Health problems as determinants of retirement: are self-rated measures endogenous?", Journal of Health Economics, Vol. 18 No. 2, pp. 173-193.

Ebbinghaus, B. (2006), Reforming Early Retirement in Europe, Japan and the USA, Oxford University Press, Oxford.

Fatas, E., Lacomba, J.A. and Lagos, F. (2007), “An experimental test on retirement decisions”, Economic Inquiry, Vol. 45 No. 3, pp. 602-614.

Feldstein, M. (1974), "Social security, induced retirement, and aggregate capital accumulation”, Journal of Political Economy, Vol. 82 No. 5, pp. 905-926.

Feldstein, M. (1996), "Social security and saving: new time series evidence", National Tax Journal, Vol. 49 No. 2, pp. 151-164.

Fisher, G.G., Infurna, F.J., Grosch, J., Stachowski, A., Faul, J.D. and Tetrick, L.E. (2014), "Mental work demands, retirement, and longitudinal trajectories of cognitive functioning", Journal of Occupational Health Psychology, Vol. 19 No. 2, pp. 231-242.

Fornero, E., Lusardi, A. and Monticone, C. (2010), "Adequacy of savings for old age in Europe", in Bovenberg, L., van Soest, A. and Zaidi, A. (Eds), Ageing, Health and Pensions in Europe: An Economic and Social Policy Perspective, Palgrave Macmillan, London, doi: 10.1057/9780230307346. 
Góra, M. (2008), "Retirement decisions, benefits and the neutrality of pension systems", available at: www.ceps.eu/system/files/book/1640.pdf (accessed 27 August 2017).

Gustafson, M.T. (2017), "The market sensitivity of retirement and defined contribution pensions: evidence from the public sector", Journal of Public Economics, Vol. 145, pp. 1-13.

Gustman, A.L., Steinmeier, T.L. and Tabatabai, N. (2010), "What the stock market decline means for the financial security and retirement choices of the near-retirement population”, Journal of Economic Perspectives, Vol. 24 No. 1, pp. 161-182.

Hagan, R., Jones, A.M. and Rice, N. (2009), "Health and retirement in Europe", International Journal of Environmental Research and Public Health, Vol. 6 No. 10, pp. 2676-2695.

Hayward, M.D., Grady, W.R., Hardy, M.A. and Sommers, D. (1989), "Occupational influences on retirement, disability, and death”, Demography, Vol. 26 No. 3, pp. 393-409.

Hochguertel, S. (2010), "Self-employment around retirement age, No. 07/2010-030", available at: https://doi.org/10.1057/9781137398390_10

Karpansalo, M., Manninen, P., Kauhanen, J., Lakka, T. and Salonen, J. (2004), "Perceived health as a predictor of early retirement", Scandinavian Journal of Work, Environment and Health, Vol. 30 No. 4, pp. 287-292.

Klapper, L. and Panos, G.A. (2011), "Financial literacy and retirement planning: the Russian case", Journal of Pension Economics and Finance, Vol. 10 No. 4, pp. 599-618.

Knoll, M.A.Z. (2010), "The role of behavioral economics and behavioral decision making in Americans' retirement savings decisions", Social Security Bulletin, Vol. 70 No. 4, pp. 1-23.

Kogut, T. and Dahan, M. (2012), "Do you look forward to retirement? Motivational biases in pension decisions", Judgement and Decision Making, Vol. 7 No. 3, pp. 282-291.

Kuhn, M. and Prettner, K. (2016), "On the long-run growth effect of raising the retirement age, No. 10/2016, Vienna", available at: www.econstor.eu/bitstream/10419/148599/1/873828895.pdf

Lacomba, J.A. and Lagos, F. (2006), "Population aging and legal retirement age”, Journal of Population Economics, Vol. 19 No. 3, pp. 507-519.

Lusardi, A. and Mitchell, O.S. (2017), "How ordinary consumers make complex economic decisions: financial literacy and retirement readiness", Quarterly Journal of Finance, Vol. 7 No. 3.

McConnell, M. (2013), "Behavioral economics and aging", The Journal of the Economics of Ageing, Vols 1/2, pp. 83-89.

McFall, B.H. (2011), "Crash and wait? The impact of the great recession on the retirement plans of older Americans", American Economic Review, Vol. 101 No. 3, pp. 40-44.

McGarry, K. (2004), "Health and retirement: do changes in health affect retirement expectations?", The Journal of Human Resources, Vol. 9 No. 3, p. 624.

Manoli, D.S. and Weber, A. (2016), "The effects of the early retirement age on retirement decisions", NBER Working Paper Series, doi: 10.3386/w22561.

Marmora, P. and Ritter, M. (2015), "Unemployment and the retirement decisions of older workers", Journal of Labor Research, Vol. 36 No. 3, pp. 274-290.

Mitchell, O. and Utkus, S. (2003), "Lessons from behavioral finance for retirement plan design, No. PRC WP 2003-6, Philadelphia", available at: http://citeseerx.ist.psu.edu/viewdoc/download?doi= 10.1.1.199.7659\&rep=rep1\&type=pdf (accessed 27 December 2017).

OECD and Eurostat (2019), "Short-term interest rates (indicator)", available at https://data.oecd.org/ interest/short-term-interest-rates.htm\#indicator-chart (accessed 8 January 2019).

Parker, S.C. and Rougier, J.C. (2007), "The retirement behaviour of the self-employed in Britain”, Applied Economics, Vol. 39 No. 6, pp. 697-713.

Peng, X. and Mai, Y. (2013), "Population ageing, retirement age extension and economic growth in China - a dynamic general equilibrium analysis, Clayton", available at: www.copsmodels.com/ ftp/workpapr/g-237.pdf (accessed 17 October 2017). 
JEFAS 26,51

Sauré, P. and Zoabi, H. (2012), "Retirement age across countries: the role of occupations, No. 2012-06", available at: www.snb.ch/n/mmr/reference/working_paper_2012_06/sourcer/reference/working _paper_2012_06/source

Schuetze, H.J. (2015), "Self-employment and retirement in Canada: the labour force dynamics of older workers", Canadian Public Policy, Vol. 41 No. 1, pp. 65-85.

Staubli, S. and Zweimüller, J. (2013), "Does raising the early retirement age increase employment of older workers?", Journal of Public Economics, Vol. 108, pp. 17-32.

Szinovacz, M.E. and Davey, A. (2005), "Predictors of perceptions of involuntary retirement", The Gerontologist, Vol. 45 No. 1, pp. 36-47.

Tapia, W. and Yermo, J. (2007), "Implications of behavioural economics for mandatory individual account pension systems, No. 11”, available at: https://doi.org/10.1787/103002825851

Van Rooij, M.C.J., Lusardi, A. and Alessie, R.J.M. (2011), "Financial literacy and retirement planning in The Netherlands", Journal of Economic Psychology, Vol. 32 No. 4, pp. 593-608.

Vermeer, N., Mastrogiacomo, M. and Van Soest, A. (2016), "Demanding occupations and the retirement age", Labour Economics, Vol. 43, pp. 159-170.

Vogel, E., Ludwig, A. and Börsch-Supan, A. (2015), "Aging and pension reform: extending the retirement age and human capital formation", Journal of Pension Economics and Finance, pp. 1-27.

Wooldridge, J.M. (2010), Econometric Analysis of Cross Section and Panel Data, The MIT Press, Cambridge, London, doi: 10.1515/humr.2003.021. 


\begin{tabular}{|c|c|c|c|c|}
\hline Indicator & Description & Factor & Source of data & \\
\hline \multicolumn{5}{|c|}{ Variables dedicated for a given gender } \\
\hline$R A$ & Pensionable age & Retirement regulations & OECD & 75 \\
\hline$A R R$ & Aggregate replacement ratio & Generosity & Eurostat & \\
\hline$H L Y$ & $\begin{array}{l}\text { Healthy life years by age } 50 \\
\text { (objective measure of health) }\end{array}$ & Demographics/Health & Eurostat & \\
\hline HEALTH & $\begin{array}{l}\text { Self-perceived health by age 55-64 } \\
\text { (subjective measure of health) } \\
\text { which expresses subjective } \\
\text { assessment by the respondent of } \\
\text { his/her health }\end{array}$ & Health & Eurostat & \\
\hline$E D U$ & $\begin{array}{l}\text { Population by educational } \\
\text { attainment level ( } 5-8 \text {, according to } \\
\text { ISCED } 2011 \text { classification) and age } \\
\text { (55-64) }\end{array}$ & Education/Knowledge & Eurostat & \\
\hline$E \& T$ & $\begin{array}{l}\text { Participation rate in education and } \\
\text { trainings by age } 50-74\end{array}$ & Education/Skills & Eurostat & \\
\hline SELF-EMP & Self-employment by age $55-74$ & Employment form & Eurostat & \\
\hline UNEMP & Unemployment rate & Labour market conditions & Eurostat & \\
\hline \multicolumn{5}{|c|}{ Variables common for both genders } \\
\hline ODR & $\begin{array}{l}\text { Old dependency ratio (the ratio } \\
\text { between population aged } 60 \text { years } \\
\text { and over and population aged } \\
20-59 \text { years) }\end{array}$ & Demographics & Eurostat & \\
\hline$I R$ & $\begin{array}{l}\text { Interest rate ("the rates at which } \\
\text { short-term borrowings are effected } \\
\text { between financial institutions or } \\
\text { the rate at which short-term } \\
\text { government paper is issued or } \\
\text { traded in the market"). }\end{array}$ & $\begin{array}{l}\text { Returns on pension } \\
\text { wealth }\end{array}$ & OECD & \\
\hline$G D P \_P C$ & $\begin{array}{l}\text { Gross domestic product per capita } \\
\text { in thousands of PPS - refers to the } \\
\text { economy and agents' incomes }\end{array}$ & Incomes & Eurostat & \\
\hline GDP_growth & $\begin{array}{l}\text { GDP at market prices - chain } \\
\text { linked volumes, percentage change } \\
\text { on previous period }\end{array}$ & $\begin{array}{l}\text { Overall economic } \\
\text { condition }\end{array}$ & Eurostat & \\
\hline$I N F$ & $\begin{array}{l}\text { Inflation - harmonized indices of } \\
\text { consumer prices, annual average } \\
\text { rate of change }\end{array}$ & $\begin{array}{l}\text { Overall economic } \\
\text { condition }\end{array}$ & Eurostat & \\
\hline \multirow[t]{2}{*}{$S \& W$} & $\begin{array}{l}\text { Salaries and wages as percentage } \\
\text { of GDP - refers to the economy } \\
\text { and measures labour factor } \\
\text { remuneration which can be } \\
\text { correlated to occupational } \\
\text { composition of the economy }\end{array}$ & $\begin{array}{l}\text { Proxy of occupational } \\
\text { composition of the } \\
\text { economy }\end{array}$ & Eurostat & $\begin{array}{r}\text { Table A1. } \\
\text { Predictor and control } \\
\text { variables }\end{array}$ \\
\hline & & & (continued) & characteristics \\
\hline
\end{tabular}


JEFAS

26,51

76

\begin{tabular}{llll}
\hline Indicator & Description & Factor & Source of data \\
\hline$L P$ & $\begin{array}{l}\text { Labour productivity (GDP per hour } \\
\text { worked) - refers to the economy } \\
\text { and measures an average }\end{array}$ & $\begin{array}{l}\text { Proxy of occupational } \\
\text { composition of the } \\
\text { determinity, which can be }\end{array}$ & OECD \\
distribution of alia by the & & \\
different professions & &
\end{tabular}

Note: *https://data.oecd.org/interest/short-term-interest-rates.htm\#indicator-chart (available at: January 8, 2019)

Table A1.

Source: OECD and Eurostat (2019)

\section{Corresponding author}

Filip Chybalski can be contacted at: filip.chybalski@p.lodz.pl

For instructions on how to order reprints of this article, please visit our website: www.emeraldgrouppublishing.com/licensing/reprints.htm

Or contact us for further details: permissions@emeraldinsight.com 